\title{
Safety signals assessed by the pharmacovigilance risk assessement committee: biologics vs conventional medicines
}

\author{
Sinais de Segurança analisados pelo comité de avaliação do risco em farmacovigilância: \\ biológicos vs terapêutica convencional
}

Margarida Estudante, Teresa Lopes, Dinah Duarte

CBIOS - Universidade Lusófona' Centro de Pesquisa de Ciências e Tecnologias da Saúde, Campo Grande, 376, 1749-024, Lisboa, Portugal

Email: margarida.estudante@ulusofona.pt

\begin{abstract}
The Pharmacovigilance Risk Assessment Committee (PRAC) is responsible for medicines safety monitoring in Europe. Biologic drugs (BDs) have more recently been developed and reinforced the treatment of serious and chronic diseases. Because of their specificities, BDs have become a new challenge for pharmacovigilance. This work evaluates safety signals generated by PRAC for BDs vs. conventional therapy (CT) between September 2012 and December 2018 (819 signals). Normalizing the results by the number of molecules (INN) in each drug class we found the proportion of safety signals by therapy type to be 4 for BDs vs. 2.5 for CT. The System Organ Classes (SOCs) affected by safety signals triggered for BDs and CT were compared. The three most relevant System Organ Classes (SOCs) found to be related to CT signals are general disorders and administration site conditions (14\%), skin and subcutaneous tissue disorders (7\%) and gastrointestinal disorders (6\%). Signals related to BDs are mainly associated with blood and lymphatic system disorders (14\%), skin and subcutaneous tissue disorders (13\%) and nervous system disorders (10\%). During the study period safety signals for BDs were proportionally 1.6 higher than safety signals for CT.
\end{abstract}

Keywords: Conventional therapy; biologics; safety signals; PRAC; pharmacovigilance

\begin{abstract}
Resumo
O Comité de Avaliação do Risco em Farmacovigilância (PRAC) monitoriza a segurança dos medicamentos na Europa. Os medicamentos biológicos $(\mathrm{MBs})$ reforçaram o tratamento de doenças graves e crónicas, mas, devido às suas especificidades, tornaram-se num desafio para a farmacovigilância. Este trabalho avalia os sinais de segurança gerados pelo PRAC para MBs vs. medicamentos tradicionais (MTs) entre setembro de 2012 e dezembro de 2018 (819 sinais). Considerando o número de moléculas (DCI) em cada classe de medicamentos, obteve-se a proporção de sinais de segurança por tipo de terapêutica: 4 para MBs vs. 2,5 para MTs. Foram comparadas as Classes de Sistemas e Órgãos (SOCs) afetadas pelos sinais de segurança gerados por MBs e MTs. As principais SOCs associadas aos sinais dos MTs são perturbações gerais e condições no local de administração (14\%), distúrbios da pele e dos tecidos subcutâneos (7\%) e doenças gastrointestinais (6\%). Para os MBs, os sinais estão principalmente relacionados com doenças do sangue e do sistema linfático (14\%), distúrbios da pele e dos tecidos subcutâneos $(13 \%)$ e do sistema nervoso (10\%). Durante o período do estudo, os sinais de segurança para MBs foram proporcionalmente 1,6 mais elevados do que os gerados para os MTs.
\end{abstract}

Palavras-Chave: Medicamentos tradicionais; biológicos; sinais de segurança; PRAC; farmacovigilância 


\section{Introduction}

All medicines are likely to cause adverse drug reactions (ADRs). Pharmacovigilance began about 170 years ago, not being recognized as such at that time $(1,2)$. Safety monitoring for all medicines throughout their lifecycles is now a regulatory requirement in order to protect public health. Pharmacovigilance methodology and regulations constitute a constant challenge as new scientific discoveries evolve (3). Since thalidomide tragedy (4) and the emergence of the first Pharmacovigilance Systems, there has been a constant evolution in the access and data processing of medicines' safety data (5).

Another important milestone occurred in 2010, with the publication of new European pharmacovigilance legislation aiming to join efforts between all Member States and the Marketing Authorisation Holders (MAHs). This new legislation focuses in the constitution of a Pharmacovigilance Risk Assessment Committee (PRAC) within the European Medicines Agency (EMA). The PRAC was formally established in July 2012 and finalized its constituion in the spring 2013 with the appointment of patient and health-care professional organization representatives as full voting members. The Committee includes independent experts in pharmacoepidemiology, clinical pharmacology, biologics, signal detection, risk communication, and vaccine vigilance (6).

This committee proactively monitors all aspects related to the safety of marked medicines, including signal evaluation and management of post-marketing benefitrisk assessments (7).

The new pharmacovigilance legislation led to the development of a set of guidelines by the EMA on good pharmacovigilance practices (GVPs) (8), and endorsed the creation of an European (EU) database, the EudraVigilance database. Eudravigilance is an EU centralized system for recording and analyzing ADRs occurred with medicines with marketing authorization in Europe, and is a main resource for safety signal detection (5). Evaluation of generated signals requires a scientific based approach in order to prioritize and manage new information. The PRAC is responsible for this task, including updating product information and restrictions for use, among other recommendations (6). Signal detection and evaluation are essential elements of current pharmacovigilance, having been extensively studied during the last few years, throughout different European projects, in order to define good signal detection practices (9-11). EMA's GVP Module IX-Signal management (12) describes the process of signal detection and validation within the EU.

A safety signal can be originated by several sources, in-

\section{Introdução}

Todos os medicamentos são suscetíveis de causar reações adversas (RAMs). A farmacovigilância teve início há cerca de 170 anos, não sendo reconhecida como tal na época $(1,2)$. A monitorização da segurança dos medicamentos ao longo do seu ciclo de vida é atualmente um requisito regulamentar como medida de proteção da saúde pública. As metodologias e regulamentação em farmacovigilância requerem uma revisão constante à medida que surgem novos avanços científicos (3). Desde a tragédia da talidomida (4) e a implementação dos primeiros Sistemas de Farmacovigilância, tem havido uma evolução constante no acesso e processamento de dados de segurança (5).

Outro marco importante ocorreu em 2010, com a publicação de nova legislação europeia (EU) em sobre farmacovigilância, destinada a unir esforços entre todos os Estados-Membros e os titulares de Autorização de Introdução no Mercado (TAIM). Esta nova legislação centra-se na constituição de um Comité de Avaliação do Risco em Farmacovigilância (PRAC) sediado na Agência Europeia do Medicamento (EMA). O PRAC foi formalmente estabelecido em julho de 2012 e finalizou a sua constituição na primavera de 2013 com a nomeação de representantes das organizações de profissionais de saúde e doentes, como membros votantes plenos. O Comité inclui peritos independentes em farmacoepidemiologia, farmacologia clínica, biologia, detecção de sinais, comunicação de riscos e vigilância de vacinas (6).

Este Comité assegura proactivamente todos os aspetos relacionados com a segurança dos medicamentos comercializados, incluindo a avaliação do sinal e o planeamento e gestão das avaliações de risco pós- comercialização (7).

A nova legislação de farmacovigilância deu origem a um conjunto de normas orientadores da EMA em boas praticas de farmacovigilância (GVPs) (8) e determinou a criação de uma base de dados Europeia (EU), a base de dados EudraVigilance. Trata-se de uma base de dados centralizada na UE para o registo e análise de RAMs reladionados com medicamentos com autorização de comercialização, constituindo um recurso fundamental para a deteção de sinais de segurança (5). A avaliação do sinal gerado requer uma abordagem científica para priorizar e gerir as novas informações. O PRAC é responsável por essa tarefa, incluindo atualização de informações sobre medicamentos, restrições de utilização, entre outras recomendações (6). A deteção e a avaliação de sinais são elementos essenciais da farmacovigilância atual, tendo sido amplamente estudadas durante os 
cluding observational and/or experimental studies. An important source of signals in drug safety is the spontaneous reporting system, which relies on the reporting of ADRs by health-care professionals and consumers to National Competent Authorities or pharmaceutical companies (13).

A signal can be related to information about a new and unknown potentially causal association, or a novel aspect of an already known association between events that requires further investigation. Differences in frequency, duration, severity, or outcome of a known association should be analyzed (12). PRAC results regarding signals identified through the regulatory European network have been subject of several publications (14, $9,15)$. This study compares the pattern of safety signals generated and published by PRAC for medicines obtained through biological sources (biological medicines or biologics) and conventional medicines over a defined time period (September 2012 to December 2018). Conventional medicines are understood as the use of drugs containing small molecules with pharmacological activity, obtained by chemical synthesis. Conventional medicines are currently the main therapeutic resource (16). Biological medicines are complex drugs produced by living organisms and have limited utilization experience, having only been launched in the 1980's (17). Biologics are macromolecules larger in size than synthetic small molecule drugs, require more resources for production, and have a higher cost. The development of biologics led to the treatment improvement of several serious and chronic diseases such as cancer, autoimmune conditions, diabetes, and anemia (18-21).

Knowledge about the safety profile of new drugs is not complete at the time of approval (Marketing Authorization - MA), primarily due to intrinsic limitations of clinical trials, among other reasons. Furthermore, during the pre-approval phase, safety profile assessment is more difficult for biologics than for chemically synthetized molecules because of limited predictability of animal studies and a high immunogenicity potential. Post-marketing safety data is therefore essential to evaluate new potential safety concerns in clinical practice. Moreover, the biologics manufacturing or formulating process may change over time (22).

Based on the different features and marketing experience of biologics in comparison to conventional medicines, we defined the primary objective of this work as a preliminary comparison of the safety signals pattern generated for biological medicines against the safety signals generated for conventional medicines, from available data (September 2012 to December 2018). To this end, we defined as secondary objectives: últimos anos por meio de diferentes projetos europeus, de modo a estabelecer boas práticas na deteção do sinal (9-11). A norma orientadora da EMA "GVP-Module IX-Signal management" (12) descreve o processo de deteção e validação do sinal a nível europeu.

Um sinal de segurança pode ter origem em várias fontes, incluindo estudos observacionais e/ ou experimentais. Uma importante fonte de sinais em matéria de segurança dos medicamentos é o sistema de notificação espontânea, que se baseia na comunicação de RAMs pelos profissionais de saúde e doentes, às Autoridades Nacionais Competentes ou às empresas pertencentes ao circuito do medicamento (13).

Um sinal consiste em informação que sugere uma nova associação potencialmente causal ou um aspeto novo de uma associação já conhecida, que requerem uma investigação mais aprofundada. As diferenças na frequência, duração, gravidade ou resultados de associações conhecidas devem ser analisados (12). Os sinais identificados pelo PRAC através da rede de farmacovigilância europeia têm sido alvo de várias publicações $(14,9,15)$. Este estudo compara o padrão de sinais de segurança gerados e publicados pelo PRAC para medicamentos obtidos por meios biológicos (medicamentos biológicos) e medicamentos convencionais num período de tempo definido (setembro de 2012 a dezembro de 2018).

Os medicamentos convencionais têm como substância ativa pequenas moléculas com atividade farmacológica, obtidas por síntese química e constituem o principal recurso terapêutico atual (16).

Os medicamentos biológicos são constituídos por complexas, produzidos por organismos vivos e cuja experiência de utilização é limitada, tendo a sua comercialização iniciado apenas na década de 1980 (17). Os medicamentos biológicos são macromoléculas de dimensões superiores às das pequenas moléculas sintéticas, exigem mais recursos na produção e são mais caros. O desenvolvimento de medicamentos biológicos melhorou o tratamento de muitas doenças graves e crónicas, como o cancro, doenças autoimunes, diabetes e anemia (18-21).

O conhecimento sobre o perfil de segurança de novos medicamentos não está completo aquando do momento da aprovação (Autorização de introdução no mercado - AIM), devido às limitações intrínsecas dos ensaios clínicos, entre outras razões. Também durante a fase de pré-aprovação, a avaliação do perfil de segurança é mais difícil para os medicamentos biológicos do que para as moléculas quimicamente sintetizadas, devido à limitada previsibilidade dos estudos em animais e a um elevado potencial de imunogenicidade. Os dados 
- the comparison of the means of signals frequencies in the biologics group and conventional medicines group; - the comparison of the three most relevant System Organ Classes (SOC) affected by the signal in the two study samples;

- the computation of the relative risk (RR) of biologics $v s$. conventional medicines by SOC.

\section{Material and Methods}

This study is designed as an observational retrospective longitudinal study. Data on the variable under analysis (safety signals generated and published by the PRAC from September 2012 to December 2018) was obtained by consulting the "List of safety signals discussed since September 2012" available at the EMA website (23). The safety signals generated and published by the PRAC were selected as the study variable due to their reliability on bringing new information on medicinal safety, resulting from the analysis of a large European ADR database (Eudravigilance) with validation by an expert committee (PRAC) (14). Other important factors associated with the selection of this variable were its open access and regular update, allowing study continuity (23).

Number of signals published by PRAC for biologics compared to conventional medicines

In order to assess differences in the means of signals published by the PRAC for biological medicines compared to conventional medicines, we used the MannWhitney nonparametric test for two independent samples with a confidence level of $95 \%$. The similarity of the distributions of the two samples was confirmed by the Levene test. Statistical treatment was performed using IBM SPSS 2019 software. de segurança pós-comercialização tornam-se assim essenciais para avaliar potenciais riscos de segurança na prática clínica. Adicionalmente, o processo de fabrico ou formulação de produtos biológicos pode alterar-se ao longo do tempo (22).

Tendo por base as especificidades e experiência de comercialização dos medicamentos biológicos relativamente aos medicamentos convencionais, definimos como objetivo primário deste trabalho a comparação preliminar do padrão de sinais de segurança gerados para medicamentos biológicos com o padrão de sinais de segurança gerados para medicamentos convencionais. Foram definidos os seguintes objetivos secundários:

- comparação das médias das frequências dos sinais na amostra de medicamentos biológicos e na amostra de medicamentos convencionais;

- comparação das 3 Classes de Orgãos e Sistemas (SOC) afetadas pelo sinal mais relevantes nas duas amostras em estudo;

- cálculo do risco relativo (RR) dos medicamentos biológicos vs. medicamentos convencionais por SOC.

\section{Material e Métodos}

Este trabalho está desenhado como estudo observacional retrospetivo longitudinal.

Os dados sobre a variável em análise (sinais de segurança gerados e publicados pelo PRAC de setembro de 2012 até dezembro de 2018) foram obtidos por consulta da "List of safety signals discussed since September 2012” disponível no sítio eletrónico da EMA (23). Os sinais de segurança gerados e publicados pelo PRAC foram selecionados como variável de estudo devido à sua robustez na informação de segurança sobre medicamentos, sendo resultantes da análise de uma grande base de dados europeia de RAMs (Eudravigilance) e avaliados por um comité de peritos (PRAC) (14). Outro fator importante na seleção desta variável foi o seu livre acesso e atualização regular, viabilizando a continuidade do estudo (23).

Número de sinais publicados pelo PRAC para medicamentos biológicos comparativamente aos medicamentos tradicionais

De forma a avaliar diferenças nas médias dos sinais publicados pelo PRAC para medicamentos biológicos comparativamente aos medicamentos tradicionais foi realizado o teste não paramétrico de Mann-Whitney para 2 amostras independentes, com um nível de confiança de $95 \%$. A semelhança das distribuições das 2 amostras foi comprovada pelo teste de Levene. $\mathrm{O}$ tra- 
Comparison of SOC associated with signals published by PRAC for biologics and conventional medicines

In order to evaluate potential differences in the distribution of signals generated by System and Organ Classes (SOCs) affected by the signal, we calculated the Relative Risk (RR) by SOC for biologicals in relation to conventional medicines $(\mathrm{RR}=$ relative frequency of biological medicines signal by SOC / relative frequency of conventional medicines signal by SOC $(24,25)$. The relative frequency of the signal per SOC for each drug class is given by the total signals in a given SOC in the drug class / total signals in the drug class.

If $\mathrm{RR}$ is greater than 1 , the relative risk of generating a signal in that SOC category is higher for the biological medicines than for the conventional medicines.

\section{Results}

Number of signals published by PRAC for biologics compared to conventional medicines

A total of 819 signals were generated by the PRAC from September 2012 to December 2018. Of these, 175 $(21.37 \%)$ originated from biological medicines and 644 (78.63\%) from conventional medicines. The number of molecules analyzed by the PRAC during the study period was different for each class of drugs: 42 molecules for biologics vs. 255 molecules for conventional medicines, therefore the sample size for conventional medicines was six times larger than the sample for biological medicines. The frequency mean of signals published in the biological medicines sample was 4.17 compared to a mean of 2.52 for conventional medicines, with statistical significant difference $(p<0.05)$. Regarding the frequency of published signals per year of study, no statistically significant differences were observed between the two samples ( $p>0.05)$ (Table 1). tamento estatístico foi efetuado no software IBM SPSS Statistics 2019.

Comparação das SOC associadas aos sinais publicados pelo PRAC para medicamentos biológicos e medicamentos tradicionais

De forma a aprofundar eventuais diferenças na distribuição dos sinais gerados por Classes de Sistemas e Órgãos (SOC) afetadas pelo sinal, calculámos o Risco Relativo (RR) por SOC para os medicamentos biológicos vs. a terapêutica convencional $(\mathrm{RR}=$ frequência relativa de sinal biológico por $\mathrm{SOC} /$ frequência relativa de sinal da terapêutica convencional por SOC) $(24,25)$. A frequência relativa do sinal por SOC para cada classe de medicamentos é dada pelo total de sinais nessa SOC nessa classe de medicamentos/ total de sinais nessa classe de medicamentos.

\section{Resultados}

Número de sinais publicados pelo PRAC para medicamentos biológicos comparativamente aos medicamentos tradicionais

Foram gerados pelo PRAC um total de 819 sinais de setembro de 2012 até dezembro de 2018. Dos mesmos, $175(21,37 \%)$ têm origem em medicamentos biológicos e $644(78,63 \%)$ em medicamentos convencionais. $\mathrm{O}$ número de moléculas analisadas pelo PRAC no período observado pelo estudo é diferente para cada classe de medicamentos: 42 moléculas para biológicos vs. 255 moléculas para medicamentos convencionais, logo a dimensão da amostra para medicamentos convencionais é seis vezes superior à da amostra de medicamentos biológicos. A média da frequência de sinais publicados na amostra de medicamentos biológicos é de 4,17 comparativamente a uma média de 2,52 para medicamentos convencionais $(p<0,05)$. Relativamente à frequência de sinais publicados por ano de estudo não se observaram diferenças estatisticamente significativas $(\mathrm{p}>0,5)$ (Tabela 1$)$. 
Table 1 / Tabela 1 - Signal distribution (absolute frequency, percentage and mean) by year and type of medicine (September 2012 until June 2018) / Distribuição de sinais (frequência absoluta, percentagem e média) por ano e tipo de medicamento (setembro de 2012 até junho de 2018). ${ }^{*} \mathrm{p}<0.05$

\begin{tabular}{|c|c|c|}
\hline Year/ Ano & $\begin{array}{c}\text { Biologics / Biológicos } \\
\quad(n=42)\end{array}$ & $\begin{array}{c}\text { Conventional/ Convencional } \\
\qquad(\mathrm{n}=255)\end{array}$ \\
\hline $\begin{array}{l}\text { September until December 2012/ } \\
\text { setembro até dezembro de } 2012\end{array}$ & $8(5 \%)$ & $38(6 \%)$ \\
\hline 2013 & $26(15 \%)$ & $97(15 \%)$ \\
\hline 2014 & $18(10 \%)$ & $99(15 \%)$ \\
\hline 2015 & $39(22 \%)$ & $102(16 \%)$ \\
\hline 2016 & $28(16 \%)$ & $103(16 \%)$ \\
\hline 2017 & $16(9 \%)$ & $100(16 \%)$ \\
\hline $\begin{array}{l}\text { January until June 2018/ } \\
\text { janeiro a junho de } 2018\end{array}$ & $40(16 \%)$ & $105(16 \%)$ \\
\hline Total/ Total & 175 (100\%) & $644(100 \%)$ \\
\hline Mean / Média & $\begin{array}{c}4.17^{*} \\
(=175 / 42)\end{array}$ & $\begin{array}{c}2.52 \\
(=644 / 255)\end{array}$ \\
\hline
\end{tabular}

Comparison of SOCs associated with signals published by PRAC for biologics and conventional medicines

The results of our study show that the three most relevant System Organ Classes (SOCs) found to be related to traditional medicines signals were general disorders and administration site conditions (14.29\%), skin and subcutaneous tissue disorders (7.45\%) and gastrointestinal disorders (6.21\%). Regarding to biological medicines, signals were mainly related to blood and lymphatic system disorders (13.71\%), skin and subcutaneous tissue disorders (13.14\%) and nervous system disorders (10.29\%) SOCs (Table 2). Results related to the computed RR are presented in Table 2 and discussed with more detail in the next section.
Comparação das SOC associadas aos sinais publicados pelo PRAC para medicamentos biológicos e medicamentos tradicionais

De acordo com os resultados do estudo, as principais SOCs relacionadas com os sinais dos medicamentos tradicionais são perturbações gerais e condições no local de administração (14,29\%; inclui interações medicamentosas, entre outras), distúrbios da pele e dos tecidos subcutâneos $(7,45 \%)$ e doenças gastrointestinais $(6,21 \%)$. No que diz respeito aos medicamentos biológicos, os sinais estão principalmente relacionados com SOC relacionadas com doenças do sangue e do sistema linfático $(13,71 \%)$, distúrbios da pele e dos tecidos subcutâneos $(13,14 \%)$ e do sistema nervoso $(10,29 \%)$ (Tabela 2$)$.

Foi ainda avaliado o Risco Relativo (RR) por SOC dos sinais pelo pelo PRAC para medicamentos biológicos em comparação com os convencionais, cujos resultados se encontram na Tabela 2 e serão discutidos na próxima seção. 
Table 2 / Tabela 2 - Relative Risk (RR) by System Organ Class Calssification (SOC) of signals raised by PRAC for biological medicines in comparison to conventional medicines. ${ }^{* *}$ not applicable / Risco Relativo (RR) por Classificação Sistema Orgão Classe (SOC) de sinais gerados pelo PRAC para medicamentos biológicos em comparação com convencionais.**não aplicável.

\begin{tabular}{|c|c|c|c|}
\hline $\begin{array}{l}\text { System Organ Class Classification (SOC) / } \\
\text { Classificação Sistema Orgão Classe (SOC) }\end{array}$ & $\begin{array}{c}\text { Biologics / } \\
\text { Biológico } \\
\text { Total\% } \\
\end{array}$ & $\begin{array}{c}\text { Conventional / } \\
\text { Convencional } \\
\text { Total \% } \\
\end{array}$ & $\begin{array}{l}\text { RR Biologics vs } \\
\text { Conventional / } \\
\text { RR Biológico vs } \\
\text { Convencional }\end{array}$ \\
\hline $\begin{array}{l}\text { Blood and lymphatic system disorders / } \\
\text { Doenças do sangue e do sistema linfático }\end{array}$ & $24(13.71)$ & $26(4.04)$ & 3.4 \\
\hline Cardiac disorders / Cardiopatias & $5(2.86)$ & $36(5.59)$ & 0.51 \\
\hline $\begin{array}{l}\text { Congenital. familial and genetic disorders/ } \\
\text { Afeções congénitas. familiares e genéticas }\end{array}$ & $0(0.00)$ & $9(1.40)$ & 0 \\
\hline $\begin{array}{l}\text { Ear and labyrinth disorders / } \\
\text { Afeções do ouvido e do labirinto }\end{array}$ & $3(1.71)$ & $2(0.31)$ & 5.52 \\
\hline Endocrine disorders / Doenças endócrinas & $3(1.71)$ & 17 (2.64) & 0.65 \\
\hline Eye disorders / Afeções oculares & $4(2.29)$ & $24(3.73)$ & 0.61 \\
\hline Gastrointestinal disorders / Doenças gastrointestinais & $8(4.57)$ & $40(6.21)$ & 0.74 \\
\hline $\begin{array}{l}\text { General disorders and administration site conditions / } \\
\text { Perturbações gerais e alterações no local de administração }\end{array}$ & $7(4.00)$ & $92(14.29)$ & 0.28 \\
\hline $\begin{array}{l}\text { Hepatobiliary disorders / } \\
\text { Afeções hepáticas e hepatobiliares }\end{array}$ & $1(0.57)$ & $14(2.17)$ & 0.26 \\
\hline Immune system disorders / Doenças do sistema imunitário & $10(5.71)$ & $16(2.48)$ & 2.3 \\
\hline Infections and infestations / Infecções e infestações & $14(8.00)$ & $15(2.33)$ & 3.43 \\
\hline $\begin{array}{l}\text { Injury. poisoning and procedural complications / Complicações } \\
\text { de intervenções relacionadas com lesões e intoxicações }\end{array}$ & $1(0.57)$ & $24(3.73)$ & 0.15 \\
\hline $\begin{array}{l}\text { Investigatory exams / } \\
\text { Exames complementares de diagnóstico }\end{array}$ & $2(1.14)$ & $22(3.42)$ & 0.33 \\
\hline $\begin{array}{l}\text { Metabolism and nutrition disorders / } \\
\text { Doenças do metabolismo e da nutrição }\end{array}$ & $4(2.29)$ & $32(4.97)$ & 0.46 \\
\hline $\begin{array}{l}\text { Musculoskeletal and connective tissue disorders / } \\
\text { Doenças musculoesqueléticas e dos tecidos conjuntivos }\end{array}$ & $4(2.29)$ & $28(4.35)$ & 0.53 \\
\hline $\begin{array}{l}\text { Neoplasms benign. malignant and unspecified (incl. cysts and } \\
\text { polyps) / Neoplasias benignas malignas e não especificadas } \\
\text { (incl. quistos e polipos) }\end{array}$ & $9(5.14)$ & $23(3.57)$ & 1.44 \\
\hline Nervous system disorders / Doenças do sistema nervoso & $18(10.29)$ & $34(5.28)$ & 1.95 \\
\hline $\begin{array}{l}\text { Pregnancy, puerperium, and perinatal conditions / } \\
\text { Situações na gravidez. no puerpério e perinatais }\end{array}$ & $1(0.57)$ & $21(3.26)$ & 0.18 \\
\hline Product problems / Problemas de produtos & $3(1.71)$ & $2(0.31)$ & 5.52 \\
\hline Psychiatric disorders / Perturbações do foro psiquiátrico & $0(0.00)$ & $23(3.57)$ & 0 \\
\hline Renal and urinary disorders / Doenças renais e urinárias & $8(4.57)$ & $22(3.42)$ & 1.34 \\
\hline $\begin{array}{l}\text { Reproductive system and breast disorders / } \\
\text { Doenças dos órgãos genitais e da mama }\end{array}$ & $0(0.00)$ & $9(1.40)$ & 0 \\
\hline $\begin{array}{l}\text { Respiratory. thoracic and mediastinal disorders / } \\
\text { Doenças respiratórias. torácicas e do mediastino }\end{array}$ & $7(4.00)$ & $35(5.43)$ & 0.74 \\
\hline $\begin{array}{l}\text { Skin and subcutaneous tissues disorders / } \\
\text { Afeções dos tecidos cutâneos e subcutâneos }\end{array}$ & $23(13.14)$ & $48(7.45)$ & 1.76 \\
\hline Social circumstances / Circunstâncias sociais & $0(0.00)$ & $0(0.00)$ & $* *$ \\
\hline $\begin{array}{l}\text { Surgical and medical procedures / } \\
\text { Procedimentos cirúrgicos e médicos }\end{array}$ & $0(0.00)$ & $1(0.16)$ & 0 \\
\hline Vascular disorders / Vasculopatias & $16(9.14)$ & $29(4.50)$ & 2.03 \\
\hline Total & $175(100 \%)$ & $\begin{array}{c}644 \\
(100 \%)\end{array}$ & $* *$ \\
\hline
\end{tabular}




\section{Discussion}

Number of signals published by PRAC for biologics compared to conventional medicines

Biologicswereonlyintroducedinthemarketinthe 1980's, and therefore it was foreseen that fewer biological medicines were present in our search, a fact that was supported by the difference found in study sample sizes (Table 1). Our results demonstrate that, during the period observed by the study, the occurrence of new safety signals for biological medicines was significantly higher than the occurrence of new safety signals for conventional medicines. The frequency mean of safety signals is 4.17 for biologics compared to 2.52 for conventional medicines $(\mathrm{p}<0.05)$ (Table 1). These results suggest that awareness and knowledge about the safety profiles of biologics are on an ascending trend, compared to conventional medicines. As more recently available medicines, with different specificities and lower marketing experience, biologics are prone to the identification of new safety signals as marketing experience increases.

Comparison of SOCs associated with signals published by PRAC for biologics and conventional medicines

The results of our study show that the three most relevant System Organ Classes (SOC) found to be related to traditional medicines signals are general disorders and administration site conditions (14.29\%), skin and subcutaneous tissue disorders $(7.45 \%)$ and gastrointestinal disorders (6.21\%). General disorders and administration site conditions SOC includes generic signals such as drug-drug interactions, withdrawn and rebound, pain and discomfort, body temperature changes, among others. These conditions are familiar as adverse reactions of conventional medicines.

Regarding to biological medicines signals were mainly related to blood and lymphatic system disorders $(13.71 \%)$, skin and subcutaneous tissue disorders (13.14\%) and nervous system disorders (10.29\%) SOC (Table 2).

The described safety profile for biologics includes ADRs that are usually linked to their pharmacologic actions and immunologic reactions, such as immunogenicity and administration-site reactions (26). This can result in a loss of efficiency or deficiency syndromes (for example, thrombocytopenia) $(27,28)$.

The relative risk (RR) for SOC of signals collected by PRAC was also evaluated for biological medicines in comparison with the conventional medicines (Table 2). If $R R$ is greater than 1 , the relative risk of generating a signal in the category of SOC was higher for

\section{Discussão}

Número de sinais publicados pelo PRAC para medicamentos biológicos comparativamente aos medicamentos convencionais

Os medicamentos biológicos foram introduzidos no mercado apenas na década de 1980 sendo expectável que menos medicamentos biológicos tenham sido encontrados nesta avaliação, em comparação com os medicamentos convencionais, facto que pode suportar a diferença na dimensão das amostras encontrada no período observado pelo estudo (Tabela 1). Foi encontrado um valor médio para a frequência de sinais publicados na amostra de medicamentos biológicos $(4,17)$ estatisticamente superior ao valor médio da amostra para medicamentos convencionais $(2,52)(\mathrm{p}<0,05)$. Sendo medicamentos mais recentes, com diferentes especificidades e uma menor experiência de comercialização, os medicamentos biológicos revelam suscetibilidade à identificação de novos sinais de segurança à medida que a experiência de utilização aumenta.

Comparação das SOC associadas aos sinais publicados pelo PRAC para medicamentos biológicos e medicamentos convencionais

De acordo com os resultados do estudo, as principais SOC relacionados com os sinais dos medicamentos convencionais são perturbações gerais e condições no local de administração, distúrbios da pele e dos tecidos subcutâneos e doenças gastrointestinais. A SOC perturbações gerais e condições no local de administração inclui sinais genéricos, tais como interações fármaco-fármaco, falta de adesão à terapêutica, síndrome de abstinência, dor e desconforto, alterações de temperatura corporal, entre outros. Estas condições são familiares como RAMs dos medicamentos tradicionais.

No que diz respeito aos medicamentos biológicos, os sinais estão principalmente relacionados com doenças do sangue e do sistema linfático, distúrbios da pele e dos tecidos subcutâneos e do sistema nervoso. As RAMs associadas aos medicamentos biológicos estão ligadas às suas ações farmacológicas e reações imunológicas, tais como reações de imunogenicidade e reações no local de administração (26). Isto pode resultar numa perda de eficácia ou de síndromes de deficiência (por exemplo, trombocitopénia) $(27,28)$.

Foi ainda avaliado o Risco Relativo (RR) por SOC dos sinais levantados pelo PRAC para fármacos biológicos em comparação com os tradicionais (Tabela 2). Se RR for superior a 1, o risco relativo da geração de um sinal na categoria dessa SOC é superior para o bioló- 
the biological compared to traditional medicines. In our analysis the SOCs with RR>1 were: disorders of the blood and lymphatic system, disorders of the immune system, infections and infestations, neoplasms (malignant, benign and unspecified), disorders of the nervous system, product problems, kidney and urinary diseases, disorders of the skin and the subcutaneous tissue, and vascular disorders. Skin and the subcutaneous tissue SOC is among the three more relevant SOC for both samples, however RR is higher for biologics. These results are in agreement with the specificities already mentioned for biological products, taking into account that they are primarily immunogenic proteins, administered intravenously and that the structural variations between batches, or a biosimilar and its reference biological, can lead to significant changes in the profile of efficacy and safety (18). Ear and labyrinth disorders appear with $R R>1$ due to a sign of deafness that has not been confirmed. The ADRs may be specific for the type of biological medicine, taking into account its mechanism of action: monoclonal antibodies, fusion proteins, enzymes and coagulation factors (mainly associated with skin reactions), cytokines (hematological disorders), and hormones (disturbance of the metabolism and nutrition) (29). Post-marketing studies confirm that the biological medicinal products, due to their effects on specific targets, have different trends in the safety profile in comparison with the conventional medicines (26).

\section{Conclusion}

The present study demonstrates that in the period observed by the study the number of signals published by PRAC for biological medicines is higher compared to the signals published for conventional medicines, which can result from an ascending trend on biologics safety profile awareness and knowledge, as they are more recently developed and complex molecules than conventional medicines. The relative risk (RR) for biological medicines is higher than for conventional medicines for signals related to the following System Organ Classes (SOC): disorders of the blood and lymphatic system, disorders of the immune system, infections and infestations, neoplasms (malignant, benign, and unspecified), disorders of the nervous system, problems with the product, kidney and urinary diseases, disorders of the skin and the subcutaneous tissue, and vascular disorders. gico relativamente aos medicamentos convencionais. $\mathrm{Na}$ nossa análise as $\mathrm{SOC}$ com $\mathrm{RR}>1$ foram: distúrbios do sistema sanguíneo e linfático, distúrbios do sistema imunológico, infeções e infestações, neoplasias benignas malignas e não especificadas, distúrbios do sistema nervoso, problemas do produto, doenças renais e urinárias, distúrbios da pele e tecido subcutâneo e distúrbios vasculares. Observamos que a SOC distúrbios da pele e dos tecidos subcutâneos se encontra entre as três mais relevantes na análise de segurança para ambos os tipos de medicamentos mas o RR é superior para os medicamentos biológicos.

Estes resultados estão de acordo com o acima mencionado para os medicamentos biológicos, tendo em conta que são principalmente proteínas imunogénicas, administradas por via intravenosa e que as variações estruturais entre lotes, ou um biosimilar e o seu biológico de referência, podem conduzir a alterações significativas no perfil de eficácia e segurança (18). Afeções do ouvido e do labirinto aparecem com RR $>1$ devido a um sinal de surdez que não foi confirmado. As RAMs podem ser específicas por tipo de biológico, tendo em conta o seu mecanismo de ação: anticorpos monoclonais, proteínas de fusão, enzimas e fatores de coagulação (associados principalmente com reações cutâneas), citoquinas (distúrbios hematológicos) e hormonas (perturbações do metabolismo e da nutrição) (29). Os estudos pós-comercialização confirmam que os medicamentos biológicos, devido aos seus efeitos em alvos específicos, possuem diferentes tendências no perfil de segurança em comparação com os medicamentos convencionais (26).

\section{Conclusão}

Com base neste estudo podemos concluir que no período observado o número de sinais publicados pelo PRAC para medicamentos biológicos foi superior comparativamente aos sinais publicados para medicamentos tradicionais. Sendo moléculas mais complexas e mais recentes, o resultado encontrado sugere que o conhecimento e consciencialização sobre o perfil de segurança para os medicamentos biológicos se encontra em fase de crescimento.

Na nossa análise as SOC com RR $>1$ para os medicamentos biológicos comparativamente aos convencionais foram: distúrbios do sistema sanguíneo e linfático, distúrbios do sistema imunológico, infeções e infestações, neoplasias benignas malignas e não especificadas, distúrbios do sistema nervoso, problemas do produto, doenças renais e urinárias, distúrbios da pele e tecido subcutâneo e distúrbios vasculares. 
These preliminary results will be further explored, namely by mechanism of action or pharmacotherapeutic class, as ADRs may be specific by type of biological medicine.

One of the limitations of this study is that signals generated from EudraVigilance cannot be isolated by country, but comparative analyses with published data from other entities, such as the World Health Organization (WHO), Food and Drug Administration (FDA) and the Australian Therapeutic Goods Administration (TGA) are planned for the near future.

\section{Conflict of Interests}

The authors declare that they have no competing interests.
Estes resultados preliminares serão aprofundados, nomeadamente no respeitante ao mecanismo de ação ou classe farmacoterapêutica, uma vez que as RAMs podem ser específicas por medicamnto biológico.

Uma das limitações deste estudo é o fato da base de dados EudraVigilance não permitir uma análise dos sinais gerados por país. Será realizada num futuro próximo uma análise comparativa com dados publicados por outras entidades, como a Organização Mundial de Saúde (OMS), a "Food and Drug Administration" (FDA) e a "Australian Therapeutic Goods Administration" (TGA).

\section{Conflito de Interesses}

Os autores declaram que não têm interesses concorrentes. 


\section{References / Referências}

1. Fornasier G, Francescon S, Leone R, Baldo P. An historical overview over Pharmacovigilance. Int J Clin Pharm. 2018;40(4):744-7.

2. Caron J, Rochoy M, Gaboriau L, Gautier S. The history of pharmacovigilance. Therapie [Internet]. 2016;71(2):129-34. Available from: http://dx.doi. org/10.1016/j.therap.2015.12.007

3. Brown P, Bahri P. 'Engagement' of patients and healthcare professionals in regulatory pharmacovigilance: establishing a conceptual and methodological framework. Eur J Clin Pharmacol. 2019;(1 September):1181-1192.

4. Klungsøyr K, Nordtveit TI, Kaastad TS, Solberg S, Sletten IN, Vik A-K. Epidemiology of limb reduction defects as registered in the Medical Birth Registry of Norway, 1970-2016: Population based study. PLoS One [Internet]. 2019;14(7):e0219930. Available from: http://dx.plos.org/10.1371/journal. pone.0219930

5. De Pretis F, Osimani B. New Insights in Computational Methods for Pharmacovigilance: E-Synthesis, a Bayesian Framework for Causal Assessment. Int J Environ Res Public Health. 2019;16(12).

6. Arlett P, Portier G, De Lisa R, Blake K, Wathion N, Dogne JM, et al. Proactively managing the risk of marketed drugs: Experience with the EMA Pharmacovigilance Risk Assessment Committee. Nat Rev Drug Discov. 2014;13(5):395-7.

7. Laroche M-L, Batz A, Géniaux H, Féchant C, Merle L, Maison P. Pharmacovigilance in Europe: Place of the Pharmacovigilance Risk Assessment Committee (PRAC) in organisation and decisional processes. Therapies. 2016;71((2)):151-160.

8. Good pharmacovigilance practices (GVPs). European Medicines Agency. Available from: https://www.ema.europa.eu/en/human-regulatory/post-authorisation/pharmacovigilance/good-pharmacovigilance-practices

9. Pacurariu AC, Coloma PM, van Haren A, Genov G, Sturkenboom MCJM, Straus SMJM. A Description of Signals During the First 18 Months of the EMA Pharmacovigilance Risk Assessment Committee. Drug Saf. 2014;37(12):1059-66.

10. Kurz X. Advancing regulatory science, advancing regulatory practice. Pharmacoepidemiol Drug Saf. 2017;26(6):722-6.

11. Wisniewski AFZ, Bate A, Bousquet C, Brueckner A, Candore G, Juhlin K, et al. Good Signal Detection Practices: Evidence from IMI PROTECT. Drug Saf. 2016;39(6):469-90.

12. Medicines Agency E. Guideline on good pharmacovigilance practices (GVP) Module IX-Signal management (Rev 1) Date of coming into effect of first version. 2017;(October 2017):1-25. Available from: www.ema.europa.eu

13. Shakir SAW. Thoughts on signal detection in pharmacovigilance. Drug Saf. 2007;30(7):603-6.

14. Potts J, Genov G, Segec A, Raine J, Straus S, Arlett P. Improving the Safety of Medicines in the EU: From signals to action. Clin Pharmacol Ther. 2019;

15. Sardella M, Lungu C. Evaluation of quantitative signal detection in EudraVigilance for orphan drugs: possible risk of false negatives. Ther Adv Drug Saf. 2019;10:1-11.

16. Sangi DP. Synthetic strategies in drug discovery: Employng diversity-oriented synthesis. Quim Nova. 2016;39(8):995-1006.

17. Kinch MS. An overview of FDA-approved biologics medicines. Drug Discov Today [Internet]. 2015;20(4):393-8. Available from: http://dx.doi. org/10.1016/j.drudis.2014.09.003

18. Kabir ER, Moreino SS, Kawsar M, Siam S. The Breakthrough of Biosimilars : A Twist in the Narrative of Biological Therapy. $2019 ; 1-34$.

19. Beaver JA, Howie LJ, Pelosof L, Kim T, Liu J, Goldberg KB, et al. A 25-year experience of us food and drug administration accelerated approval of malignant hematology and oncology drugs and biologics a review. JAMA Oncol. 2018;4(6):849-56.

20. Danne T, Heinemann L, Bolinder J. New Insulins, Biosimilars, and Insulin Therapy. Diabetes Technol Ther. 2019;21(S1):S57-78.

21. Inotai A, Prins CPJ, Csanádi M, Vitezic D, Codreanu C, Kaló Z. Is there a reason for concern or is it just hype?-A systematic literature review of the clinical consequences of switching from originator biologics to biosimilars. Expert Opin Biol Ther [Internet]. 2017;17(8):915-26. Available from: https://doi. org/10.1080/14712598.2017.1341486

22. Vezér B, Buzás Z, Sebeszta M, Zrubka Z. Authorized manufacturing changes for therapeutic monoclonal antibodies (mAbs) in European Public Assessment Report (EPAR) documents. Curr Med Res Opin. 2016;32(5):829-34.

23. List of signals discussed at PRAC since September 2012 [Internet]. Available from: https://www.ema.europa.eu/en/human-regulatory/post-authorisation/ pharmacovigilance/signal-management/prac-recommendations-safety-signals\#list-of-safety-signals-discussed-since-september-2012-section

24. Simon SD. Andrology Lab Corner Understanding the Odds Ratio and the Relative Risk. J Androl [Internet]. 2001;22(4). Available from: https://onlinelibrary.wiley.com/doi/pdf/10.1002/j.1939-4640.2001.tb02212.x

25. Glantz stanton a. primer of biostatistics. 2005;(6):164.

26. Giezen TJ, Mantel-Teeuwisse AK, Meyboom RHB, Straus SMJM, Leufkens HGM, Egberts TCG. Mapping the Safety Profile of Biologicals. Drug Saf. 2010;33(10):865-78

27. Sauna ZE, Lagassé D, Pedras-Vasconcelos J, Golding B, Rosenberg AS. Evaluating and Mitigating the Immunogenicity of Therapeutic Proteins. Trends Biotechnol [Internet]. 2018;36(10):1068-84. Available from: https://doi.org/10.1016/j.tibtech.2018.05.008

28. Bennett CL, Luminari S, Nissenson AR, Tallman MS, Klinge SA, McWilliams N, et al. Pure red-cell aplasia and epoetin therapy. N Engl J Med. 2004;351(14):1403-8.

29. Ingrasciotta Y, Cutroneo PM, Marcianò I, Giezen T, Atzeni F, Trifirò G. Safety of Biologics, Including Biosimilars: Perspectives on Current Status and Future Direction. Drug Saf. 2018;41(11):1013-1022 